\title{
PENDIDIKAN AGAMA ISLAM DI ERA INFORMASI SEBAGAI PEMBENTUKAN AKHLAK PESERTA DIDIK
}

Oleh : Hibrul Umam*

\begin{abstract}
Abstrak
Islamic religious education is an urgent matter to be studied for every human being, especially Muslims, because these subjects are very important for students especially in public schools. If not surprised, many students commit crimes everywhere, such as robbing, doing sex outside of marriage, disobeying both parents, not performing prayer and so on. So do not be surprised if Islamic religious education subjects are expected to be able to provide a thirst for their thirst (students) for the meaning of life and the importance of the future. Because Islamic religious education has a principle as a process of self-development, free education, education that is full of human and divine values, principles of life balance, principles of equality, principles of a lifetime, and self-principles. Islamic religious education subjects at least provide or shape the character of students especially in public schools with various approaches both cognitive, affective, and behavioral.
\end{abstract}

Kata Kunci: Islamic religious education, Moral Formation, Students

*Hibrul Umam adalah Dosen Prodi PAI Sekolah Tinggi Ilmu Tarbiyah Makhdum Ibrahim Tuban.

\section{A. Pendahuluan}

Pada era informasi dan pasar bebas, perkembangan teknologi dan informasi yang begitu cepat persaingan antar industri semakin ketat dalam menghasilkan produksi yang lebih efektif, efisien, dan serba cepat. Perkembangan teknologi dan informasi yang cepat, perlu diimbangi dengan kualitas sumber daya manusia (SDM) yang tangguh (Sugeng Listyo, 2013:7) Di sisi lain masih banyak kita temui kenakalan di kalangan pelajar dan mahasiswa, adanya tawuran antar pelajar, kebiasaan "menyontek" pada saat ulangan/ujian, keinginan lulus dengan cara mudah tanpa kerja keras/belajar, mulai bergesernya etika/ sopan santun, rendahnya kejujuran, rendahnya tanggungjawab dan kedisiplin, internetan saat sedang kuliah, banyak kasus gadis pergi dari rumahnya dengan teman yang baru dikenal lewat facebook dan lain-lain. Ini semua menunjukkan betapa rapuhnya karakter di kalangan pelajar di lingkungan sekolah umum. 
Proses perkembangan karakter pada seseorang siswa di sekolah umum dipengaruhi oleh banyak faktor yang khas baik faktor bawaan (nature) dan lingkungan (nurture) dimana orang yang bersangkutan tumbuh dan berkembang (Sri Palupi, 2011). Sebenarnya pembentukan karakter siswa sudah dilakukan di berbagai perguruan tinggi baik negeri maupun swasta termasuk dengan mengikuti organisasiorganisasi yang ada di dalamnya, namun dalam hal itu semua masih belum membentuk secara jeneral kepada mahasiswa khususnya dalam karakter mahasiswa. Maka dengan tersebut diperlukan jalan lain yang diharapkan mampu secara benarbenar membentuk karakter mahasiswa yaitu dengan melalui "Pendidikan Agama Islam", karena ilmu tersebut diharapkan mampu memberikan kontribusi yang signifikan dalam pembentukan karakter mahasiswa di perguruan tinggi, baik di perguruan tinggi negeri maupun swasta.

Menurut Azyumardi Azra bahwa ada beberapa masalah pokok di lingkungan perguruan tinggi yaitu menyangkut krisis mentalitas dan moral mahasiswa yang turut menjadi akar krisis mentalitas dan moral di lingkungan perguruan tinggi. Hal tersebut disebabkan dengan beberapa faktor diantaranya adalah: (Azyumardi Azra , 2012:20-21) pertama, arah pendidikan telah kehilangan obyektivitasnya., Kedua, proses pendewasaan diri tidak berlangsung baik di lingkungan sekolah umum. Ketiga, proses pendidikan di sekolah umum sangat membelenggu siswa dan bahkan juga dosen. Keempat, beban kurikulum yang demikian berat, lebih parah lagi hampir sepenuhnya diorientasikan pada pengembangan ranah koqnitif belaka. Kelima, meskipun ada materi yang dapat menumbuhkan rasa afeksi seperti mata kuliah agama ia umumnya disampaikan dalam bentuk verbalisme, yang juga disertai dengan rote-memorizing. Keenam, pada saat yang sama siswa dihadapkan kepada nilai-nilai yang sering bertentangan (contradictory set of values). Ketujuh, para siswa mengalami kesulitan dalam mencari contoh teladan yang baik (uswah hasanah/living moral exemplary) di lingkungannya.

Masalah-masalah tersebut perlu adanya keseriusan, sehingga nantinya para siswa menemukan solusinya dalam masalah yang mereka hadapi. Karena seperti apapun sekolah umum perlu bergerak secara cepat untuk mengatasi masalah-masalah yang berkaitan dengan masalah etika atau karakter yang yang terjadi di lingkungan sekolah umum. Memang untuk menghadapi itu semua tidak mudah, karena itu semua 
berkaitan dengan banyak orang, perlu dirumuskan secara bersama, sehingga hasilnya akan maksimal pula. Dengan demikian, maka pembelajaran pendidikan agama Islam adalah sebagai solusinya untuk untuk memberikan dan pembentukan karakter terhadap siswa di sekolah umum.

\section{B. Pendidikan Agama Islam dalam Kehidupan peserta didik}

\section{Kebutuhan Mata Pelajaran Pendidikan Agama Islam}

Sebagaimana pengertian tentang pendidikan agama Islam dapat diartikan bimbingan secara sadar oleh pendidik terhadap perkembangan jasmani dan rohani peserta didik menuju terbentuknya kepribadian yang utama. Maka, pendidikan agama Islam dipandang sebagai salah satu aspek yang memiliki peranan pokok dalam membentuk generasi muda agar memiliki kepribadian yang utama. Dengan pengertian tersebut, unsur-unsur yang ada dalam pendidikan agama Islam mempunyai ciri khas yaitu: 1) Membantu pembentukan akhlak yang mulia, 2) Usaha (kegiatan) yang bersifat membimbing dan dilakukan secara sadar, 3) Pendidik atau pembimbing, 4) Peserta didik, 5) Bimbingan yang mempunyai dasar dan tujuan, dan 6) Menyiapkan pelajaran dari segi profesional, teknis, supaya dapat menguasai profesi, dan kerampilan tertentu agar ia dapat mencapai rezeki dalam hidup disamping memelihara segi kerohanian.( Zuhairini, dkk, 2004: 1)

Tujuan pendidikan agama Islam menurut Zakiah Daradjad yaitu membina manusia beragama berarti manusia yang mampu melaksanakan ajaran-ajaran agama Islam dengan baik dan sempurna, sehingga tercermin pada sikap dan tindakan dalam seluruh kehidupannya, dalam rangka mencapai kebahagiaan dan kejayaan dunia dan akhirat. Yang dapat dibina melalui pengajaran agama yang intensif dan efektif.( Zakiah Daradjad ,1995:172).

Dengan kata lain bahwa tujuan hidup setiap Muslim adalah menghambakan diri kepada-Nya. Hal ini sesuai dengan rirman Allah Q.S. Ali-Imron ayat 102 yang berbunyi:

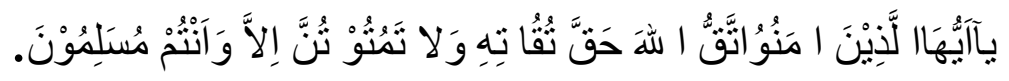

Artinya:"Wahai orang-orang yang beriman, bertaqwalah kamu kepada Allah dengan sebenar-benarnya taqwa dan janganlah kamu mati kecuali dalam keadaan muslim berserah diri kepada Allah". 
Artinya berserah diri inilah merupakan tujuan akhir dari proses hidup dan ini merupakan isi kegiatan pendidikan. Ini akhir dari proses pendidikan yang dapat dianggap sebagai tujuan akhir dari pendidikan Agama Islam. Jadi menurut al-Ghazali ada dua tujuan pendidikan yang ingin dicapai sekaligus, pertama kesempurnaan manusia yang bertujuan mendekatkan diri, dalam arti kualitatif kepada Allah Swt, kedua kesempurnaan manusia yang dimaksud adalah kebahagiaan di dunia dan akhirat. Untuk menjadikan insan kamil (manusia paripurna) tidaklah tercipta dalam sekejap mata, tetapi mengalami proses yang panjang dan ada prasyarat-prasyarat yang harus dipenuhi di antaranya mempelajari beberapa ilmu, mengamalkannya dan menghadapi berbagai cobaan yang mungkin terjadi dalam proses pendidikan itu.

Marimba dalam bukunya Pengantar filsafat Pendidikan Islam, menyatakan tujuan akhir pendidikan agama Islam adalah terbentuknya kepribadian Muslim. Dari beberapa pendapat tersebut di atas maka dapat ditarik suatu pengertian bahwa tujuan pendidikan agama Islam yaitu mencapai keseimbangan pertumbuhan diri pribadi manusia Muslim secara menyeluruh melalui latihan kejiwaan, akal pikiran, kecerdasan, perasaan dan pancaindera sehingga memiliki kepribadian yang utama. Oleh karena itu, pendidikan agama Islam harus mengembangkan seluruh aspek kehidupan manusia baik spiritual, intelektual, imajinasi (fantasi), jasmani, keilmiahan, bahasa, serta mendorong aspek-aspek itu ke arah kebaikan atau kesempurnaan hidup.( Marimba ,1985: 8).

Dengan menguraikan yang berkaitan dengan pengertian PAI dan tujuan PAI, maka jelas bahwa mata pelajaran PAI di sekolah umum sangat penting, karena dengan mata pelajaran tersebut diharapkan mampu memberikan pendidikan yang mengarah pada akhlak atau etika seorang anak/siswa dalam kehidupan sehariharinya. Selain itu pula pendidikan agama Islam tidak hanya mengajarkan tentang shalat, puasa, zakat dan haji, namun pendidikan agama Islam di sekolah memberikan wawasan kepada peserta secara universal. Sehingga peserta didik memahami tentang PAI di sekolah umum bukan sekedar kebutuhan mata pelajaran belaka akan tetapi mata pelajaran tersebut memberikan sumbangsih wawasan yang luas.

\section{Prinsip-prinsip Pendidikan Agama Islam}

Prinsip-prinsip pendidikan agama Islam yang biasa diterapkan di sekolah antara lain yaitu:( Marimba,1985:83) pertama, pendidikan agama Islam sebagai suatu 
proses pengembangan diri. Manusia adalah makhluk paedagogik, yaitu makhluk Allah yang dapat dididik dan dapat mendidik. Potensi ini merupakan pemberian Allah berupa akal-pikiran, perasaan, nurani, yang akan dijalankan manusia baik sebagai makhluk individu maupun sebagai makhluk yang bermasyarakat. Potensi yang besar tidak akan bisa kita manfaatkan jika kita tidak berusaha untuk mengaktifkan, mengembangkan dan melatihnya. Hal itu membutuhkan sebuah proses yang akan memakan waktu, tenaga bahkan biaya, tetapi mengingat potensi yang luar biasa yang kita akan raih hal itu tidak ada artinya apa-apa. Jadi pendidikan adalah proses untuk mengembangakan potensi diri.

Kedua, pendidikan Islam adalah pendidikan yang bebas. Manusia merupakan makhluk ciptaan Allah yang diberikan kebebasan dalam berkehendak dan memilih,namun kebebasan yang dimiliki oleh manusia harus tetap berada dalam aturan-aturan yang telah ditetapkan oleh Allah sebagai pencipta dari manusia tersebut agar kehidupan manusia berjalan di atas rel yang telah ditentukan Allah untuk mencapai keselamatan di dunia dan di akhirat nanti.( Zakiah Daradjad' 1983:87). Dalam hal ini pendidik bertuugas mengarahkan dan menuntun peserta didik dalam kehidupannya.

Ketiga, pendidikan Islam penuh dengan nilai insaniah dan ilahiyah. Sumber akhlak manusia yang terbaik adalah agama Islam dimana kedudukan akhlak sangatlah penting sebagai pelengkap dalam menjalankan fungsi kemanusiaan di bumi. Pendidikan merupakan proses pembinaan akhlak pada jiwa. Meletakkan nilainilai moral pada anak didik harus diutamakan. Nilai-nilai ketuhanan harus dikedepankan, pendidikan Islam haruslah memperhatikan pendidikan akhlak atau nilai dalam setiap pelajaran dari tingkat dasar sampai tingkat tertinggi dan mengutamakan fadhilah dan sendi moral yang sempurna.

Keempat, prinsip keseimbangan hidup. Dalam pendidikan Islam prinsip keseimbangan meliputi; (1) keseimbangan antara kehidupan dunia dan akhirat, (2) Keseimbangan antara kebutuhan jasmanai dan rohani, (3) Keseimbangan antara kepentingan individu dan sosial, dan (4) Keseimbangan antara ilmu pengetahuan dan amal. Prinsip ini telah ditegaskan dalam al-Qur'an dan carilah pada apa yang telah dianugerahkan kepadamu (kebahagiaan) negeri akhirat, dan jaganlah kamu 
melupakan kebahagiaan dari kenikmatan duniawi dan berbuat baiklah (kepada orang lain) sebagaimana Allah telah berbuat baik kepadamu.

Kelima, prinsip persamaan. Kesempatan belajar dalam Islam sama antara laki-laki dan perempuan, oleh karena itu kewajiban untuk menuntut ilmu juga sama. Sistem pendidikan tidak mengenal perbedaan dan tidak membeda-bedakan latar belakang orang itu jika dia mau menuntut ilmu. Semua punya potensi yang sama untuk di didik dan punya kesempatan yang sama untuk memproses diri dalam pendidikan.

Keenam, prinsip seumur hidup, sepanjang masa. Pendidikan yang dianjurkan tidak mengenal batas waktu, tidak mengenal umur. Seumur hidup manusia harunya terdidik, mulai dari lahir sampai ke liang lahat. Seluruh kehidupan kita digunakan sebagai proses pendidikan, sebagai proses untuk menjadi hamba yang baik, menjadi insan kamil.

Ketujuh, prinsip diri. Orang telah kehilangan kepercayaan kepada diri sendiri. Sebenarnya sudah mati sebelum mereka hidup, sebab tidak bisa melihat dunia dengan potensi panca indranya sendiri. Manusia adalah makhluk yang sempurna dengan berbekal akal, perasaan yang bisa dikembangkan. dengan inilah harkat manusia lsebih tinggi di banding makhluk lainnya. Atau bahkan karena akalnyapun manusia bisa unggul dari manusia satu dengan manusia lainnya.

\section{Metode Pembelajaran PAI di Era Informasi}

Secara garis besar beberapa ahli juga menjelaskan hal yang sama tentang metode-metode pembelajaran yang bisa dipakai dalam PAI sebagaimana yang disebutkan. Berbagai macam metode pendidikan agama Islam bahwa dalam implikasinya tidak hanya menggunakan satu metode, namun tergangtung dari kebutuhan itu sendiri. Dalam belajar mengajar terkandung dua kegiatan pokok, yaitu kegiatan guru dalam mengajar dan kegiatan murid dalam belajar-mengajar pada umumnya diartikan sebagai usaha guru untuk menciptakan kondisi-kondisi atau mengatur lingkungan sedemikian rupa sehingga terjadi interaksi antara murid dengan lingkungannya, termasuk guru, alat pelajaran, kurikulum dan instrument pendidikan pendidikan lainnya yang disebut proses belajar sehingga tercapai tujuan pelajaran yang telah ditetapkan. Berbagai macam teori belajar telah dikenal dan masingmasing dapat memberi sumbangan tertentu mengenal proses belajar. Namun 
demikian, belum ada satu teori belajar yang dapat dijadikan pegangan untuk segala jenis belajar karena berbagai jenis belajar ditentukan menurut tujuannya.

Dengan demikian, ada sejumlah cara yang dapat ditempuh atau sejumlah metode interaksi yang dapat dipertimbangkan sebagai alternatif-alternatif untuk membina tingkah laku belajar secara edukatif dalam berbagai peristiwa interaksi. Di antara kemungkinan-kemungkinan yang dapat ditempuh adalah sebagai berikut: 1) Menyampaikan penerapan atau informasi melalui metode ceramah, 2) Membuka dialog melalui kegiatan tanya jawab 3) Mencari berbagai alternatif pemecahan masalah melalui diskusi, 4) Meningkatkan ketrampilan melalui berbagai latihan siap, (drill) 5) Memberikan contoh dan memperjelas pengalaman dengan melalui demontrasi dan eksperimen, 6) Memupuk pengetahuan melalui pelaksanaan tugas dan simulasi, 7) Memperluas dan memperkaya pengalaman melalui karyawisata, 8) Memupuk kerja sama atau gotong-royong melalui pengalaman kerja, 9) kelompok dan tugas-tugas diluar sekolah, 10) Memerankan cara tingkah laku dengan cara berperan menjadi pemain atau sosio drama, 11) Menerapkan kerja sama antar kelompok peserta didik dengan menggunakan sistem regu, 12) Memupuk kreativitas, berpikir kritis dan analisis dengan menggunakan metode proyek (Achmad Patoni, 2013:133).

Dalam pendidikan agama Islam, hampir semua bahan dan materinya dapat disampaikan dengan metode ceramah, baik yang menyangkut akidah, syariah, maupun, akhlak. Hanya saja di dalam penerapannya hendaknya dipadukan dengan metode-metode yang lain sekiranya memungkinkan dan dibantu alat-alat bantu mengajar lainnya serta peragaan.

Dengan berbagai uraian tersebut di atas, maka jelas bahwa nilai-nilai pembelajaran pendidikan agama Islam memberikan kontribusi yang sangat luar biasa bagi perubahan-perubahan karakter siswa. Dalam pendidikan agama Islam memberikan sumbangsih khususnya dalam pembentukan karakter siswa yang positif (Mulyasa' 2007:111). Karena seperti apapun pendidikan agama Islam khususnya di sekolah umum sangat membantu dalam pembentukan karakter siswa, sehingga siswa sangat terbantu dalam proses pembelajaran PAI.

Sebagai mata pelajaran, pendidikan agama Islam (PAI) memiliki peranan penting dalam penyadaran nilai-nilai agama Islam kepada peserta didik. Muatan mata 
pelajaran yang mengandung nilai, moral, dan etika agama menempatkan PAI pada posisi terdepan dalam pengembangan moral beragama peserta didik. Hal itu sekaligus berimplikasi pada tugas-tugas dosen PAI yang kemudian dituntut lebih banyak perannya dalam penyadaran nilai-nilai keagamaan.( Rohmat Mulyana ,2004:198).

Beberapa karakteristik PAI sebagai mata pelajaran sebagai berikut: 1) PAI merupakan mata kuliah yang dikembangkan dari ajaran-ajaran pokok agama Islam, 2) PAI bertujuan membentuk siswa agar beriman dan bertaqwa kepada Allah Swt. Serta memiliki akhlak mulia, 3) PAI mencakup tiga kerangka dasar, yaitu aqidah, syariah, dan akhlak, dan 4) PAI bertujuan memberikan motivasi untuk meningkatkan skill-skill yang mereka miliki.

Berdasarkan karakteristik di atas, maka PAI jelas berbeda dengan mata pelajaran lainnya. Muatan inti PAI adalah nilai-nilai kebenaran dan kebaikan (juga keindahan) yang berasal dari wahyu. Nilai-nilai itu tercakup dalam tiga kerangka dasar PAI yang harus dikusai oleh peserta didik atau siswa (Winarno Surahmat, 2000:94).

Apabila hal itu dikaitkan dengan pendidikan nilai, maka persoalan utama yang menjadi tanggungjawab guru PAI adalah bagaimana agar pengetahuan tentang tiga kerangka dasar itu menyatu dengan kesadaran yang optimal terhadap nilai-nilai yang terkandung di dalamnya. Walaupun mudah diprediksi bahwa belajar sebuah ayat al-Qur' an atau al-Hadis secara inherent melibatkan nilai, perlu dipikirkan caracara terbaik agar peserta didik, selain hafal dan mengerti, juga ia memiliki kesadaran yang tinggi untuk melakukannya. Oleh karenanya, kebiasaan mengajar yang terjadi selama ini memerlukan perluasan cara yang lebih eksploratif baik induktif maupun deduktif.

\section{Pembentukan Ahkalaq Peserta didik}

\section{Pendekatan Ahkalaq Peserta didik}

Sebelum membahas tentang akhalaq peserta didik setidaknya terlebih dahulu memahami tentang kata-kata "pembentukan". Dalam kamus besar bahasa Indonesia bahwa pembentukan adalah proses, cara dan perbuatan membentuk. Dengan demikian, maka dapat dipahami bahwa pembentukan merupakan sebuah proses atau 
cara dalam melakukan aktivitas. Namun hal ini tidak akan berarti tanpa ada sebuah sisipan dari kata lain (Pusat Bahasa Deparetemen Pendidikan Nasional, 2007:136).

Pengertian karakter menurut Pusat Bahasa Depdiknas adalah "bawaan, hati, jiwa, kepribadian, budi pekerti, perilaku, personalitas, sifat, tabiat, temperamen, dan watak". Adapun berkarakter adalah berkepribadian, berperilaku, bersifat, bertabiat dan berwatak. Menurut Tadkiroatun Musfiroh karakter mengacu kepada serangkaian sikap (attitude), perilaku (behavior), motivasi (motivation) dan keterampilan (skill). Karekter berasal dari kata Yunani yang berarti "to mark" atau menandai dan memfokuskan bagaimana mengaplikasikan nilai kebaikan dalam bentuk tindakan atau tingkah laku sehingga orang yang tidak jujur, kejam, rakus dan perilaku jelek lainnya dikatakan orang berkarakter jelek. Sebaliknya, orang yang berperilakunya sesuai dengan kaidah moral disebut dengan berkarakter mulia, sekaligus mampu berprilaku yang sesuai dengan norma-norma yang ada baik agama, social maupun adat yang ada(Tadkiroatun Musfiroh,2011:93).

Menurut Hersh, setidaknya ada lima pendekatan yang sering digunakan oleh para pakar pendidikan yaitu; (1) pendekatan pengembangan rasional, (2) pendekatan pertimbangan, (3) pendekatan klarifikasi nilai, (4) pendekatan pengembangan moral kognitif, dan (5) pendekatan perilaku sosial.( R.H., Miller J.P. Hersh \& Fielding, G.D,1980:170). Terkait dengan itu, Elias mengklarifikasikan berbagai teori yang berkembang menjadi tiga yaitu (1) pendekatan kognitif, (2) pendekatan afektif, dan (3) pendekatan perilaku. Klasifikasi ini menurut Rest didasarkan pada tiga unsur moralitas, yang biasa menjadi tumpuan kajian psikologi, yaitu perilaku, kognisi, dan afeksi.( J.R. Rest,1992:71).

Kajian tentang aneka pendekatan pendidikan karakter dalam pembahasan berikut didasarkan pada aneka pendekatan seperti yang telah dikaji dan dirumuskan tipologinya dengan jelas oleh Superka. Ketika menyelesaikan pendidikan tingkat doktor di University of California, Berkeley, tahun 1973 dalam bidang pendidikan menengah Superka telah melakukan kajian dan merumuskan tipologi dari berbagai pendekatan pendidikan karakter yang berkembang dan digunakan dalam dunia pendidikan. Dalam kajian tersebut dibahas delapan pendekatan pendidikan nilai berdasarkan kepada berbagai literatur dalam bidang psikologi, sosiologi, filosofi, dan pendidikan yang berhubungan dengan nilai. Selanjutnya, berdasarkan hasil 
pembahasan dengan para pendidik dan alasan-alasan praktis dalam penggunaannya di lapangan, berbagai pendekatan tersebut telah diringkas menjadi lima tipologi pendekatan, yaitu (1) pendekatan penanaman nilai (inculcation approach), (2) pendekatan perkembangan moral kognitif (cognitive moral development approach), (3) pendekatan analisis nilai (values analysis approach), (4) pendekatan klarifikasi nilai (values clarification approach), dan (5) pendekatan pembelajaran berbuat (action learning approach). Uraian lebih lanjut dalam pembahasan ini akan didasarkan pada lima pendekatan tersebut. Kelima pendekatan ini, selain telah dikaji dan dirumuskan tipologinya dengan jelas oleh Superka, juga dipandang sesuai dan bermanfaat dalam pelaksanaan pendidikan karakter di Indonesia.

\section{Penerapan Nilai-nilai Pembentukan akhalaq peserta didik di era informasi}

Setidaknya dalam penerapan nilai-nilai pembentukan karakter siswa di sekolah sangatlah luas, maka dalam penulisan ini penulis sengaja mengambil dengan model iqra', fikir dan dzikir. Hal tersebut mampu membentuk karakter siswa yang matang, karena kalau berbicara masalah pendidikan agama Islam sangat luas, maka bagi penulis cukup tiga tersebut dalam pembentukan karakter siswa. Dalam istilah yang sering digunakan oleh banyak kalangan khususnya para kalangan akademisinya bahwa istilah life long education (belajar sepanjang hayat). UNESCO mencanangkan empat pilar pendidikan, yaitu: (1) learning to know, yang juga berarti learning to learn, yaitu belajar untuk memperoleh pengetahun dan untuk melakukan pembelajaran selanjutnya, (2) learning to do, yaitu belajar untuk memiliki kompetensi dasar dalam berhubungan dengan situasi dan tim kerja yang berbedabeda, (3) learning to life together, yaitu belajar untuk mampu mengapresiasi dan mengamalkan kondisi saling ketergantungan, keanekaragaman, memahami dan pendamaian intern dan antar bangsa, dan (4) learning to be, yaitu belajar untuk mengaktualisasikan diri sebagai individu dengan kepribadian yang memiliki timbangan dan tanggungjawab pribadi.( Superka,2012:99).

Dalam pembentukan karakter setiap orang tidak boleh berhenti untuk belajar karena di setiap saat, setiap orang harus menghadapi berbagai masalah yang berbeda. Cari ilmu sejak lahir sampai liang lahat (al-Hadis). Dengan penjelasan tersebut menunjukkan indikasi bahwa akan pentingnya ilmu, sehingga nabi Muhammad Saw, 
memerintahkan kepada umatnya mulai belajar dari lahir sampai meninggal. Dalam konteks tersebut bahwa belajar tidak hanya pada pendidikan formal saja, akan tetapi dimanapun berada maka disitulah mempunyai tugas untuk belajar.

Menurut B.S. Wibowo bahwa teori tentang belajar adalah dengan cara iqra learning, dan konsep ini penulis mengungkapkan bawha: I adalah inquiry, penyelidikan. Model belajar inquiry adalah belajar mandiri dengan menggali apa yang kita lihat, dengar, baca, perhatikan, alami, dan rasakan. Selalu mengadakan penyelidikan, self exploration atau menerapkan teori tarbiyah dzatiyah. Dengan demikian, hendaknya murid selalu mandiri dalam mencari kebenaran, secara aktif mencari informasi sehubungan menjawab rasa ingin tahu yang timbul di dalam dirinya. Model belajar inquiry yang paling hebat adalah model belajarnya nabi Ibrahim dalam mencari Tuhan Allah (kebenaran) atau sahabat al-Farisi dalam mencari Rasulullah.

Berikutnya Q ialah Question, bertanya. Model belajar yang tumbuh dalam diri adalah untuk memenuhi rasa ingin tahun. Melakukan konfirmasi, menyusun hipotesa terus bertanya dalam memenuhi rasa ingin tahunya. Ilmu adalah perbendaharaan dan kuncinya adalah pertanyaan. Hendaklah setiap anak mengajukan pertanyaan tentang apa manfaatnya mengikuti pendidikan, materi apakah yang paling saya butuhkan, dan bagaimana menyelesaikan kebutuhan belajar pribadi saya.

Selanjutnya R ialah Repeat, mengulang. Melakukan revieu terhadap apa yang telah diterima, karena hal ini dimaksudkan untuk menyimpan data dari memori jangka pendek ke jangka panjang. Nabi Adam setelah diajarkan olah namanamabenda, kemudian disuruh me-recall seluruh informasi yang telah diterima dengan menyampaikan kepada malaikat dan jin. Ingat, ulangi proses belajar kembali walaupun hanya sesaat dan formulasikan dengan bahasa sendiri, akan lebih baik bagi memori. Peran guru dalam hal ini harus mampu merangsang anak untuk me-repeat kembali dengan cara mengapersepsi pelajaran lalu dengan pelajaran baru yang akan disampaikannya.

Terakhir A ialah Action, puncah belajara adalah amal, apa yang telah kita pahami perlu diaplikasikan. Amal adalah buah ilmu, dengan penerapan amal maka kita akan kembali menemukan ilmu baru. Dengan amal, maka kita akan melakukan sintesa antara teori dengan aplikasi, inilah puncak ilmu. Bukankah pengalaman 
adalah guru yang paling utama. Sebaiknya setiap murid selalu segera mengamalkan seluruh pemahaman. Di sinilah awal kegagalan dalam belajar, orang hanya mengumpulkan informasi, namun tidak segera mengamalkan apa yang diketahuinya.

Langkah berikutnya adalah menerapka FIKIR sebagai makna dari amal. FIKIR dalam hal ini mengandung pengertian yaitu: pertama, F adalah Fun, yaitu belajar untuk mengaktualisasikan diri sebagai individu dengan kepribadian yang memiliki timbangan dna tanggungjawab pribadi. Terciptanya suatu kegiatan belajar yang menyenangkan, tidak tertekan, gembira, flow dan enjoy.

Kedua I adalah Ijtihad, pintu ijtihad, kreatifitas dan inovasi terbuka dalam Islam. Kita akan berada pada puncak belajar ketika mampu melakukan sintesa atas seluruh kerangka pemikiran yang telah kita miliki, kemudian muncul ide baru yang unik. Ketiga, K ialah Konsep, belajar mengumpulkan konsep, rumusan, model, pola dan teknik, sebagai dasar untuk mengembangkannya dalam konteks yang lebih luas.

Keempat I adalah Imajinasi, Imajinasi dapat menghadirkan yang baru yang asalnya tidak ada menjadi ada. Belajar membangun imajinasi untuk menciptakan sesuatu yang benar-benar baru. Dan kelima merupakan $\mathrm{R}$ adalah Rapi, jika ingin sukses, maka biasakan dengan catatan-catatan yang baik serta mampu mengorganisasikan materi dengan baik. Dengan demikian guru harus mampu mendorong peserta didik untuk memiliki catatan yang rapi, lengkap dan baik pula.

Menerapkan dzikir, yang merupakan makna dari fikir. Dzikir dalam hal ini diartikan sebagai doa, ziarah, iman, komitmen, ikrar, dan realitas.( Buku Tarbiyah Menjawab Tantangan,2012:147). Pembentukan karakter siswa sangatlah penting mengingat akan fungsi dan tujuan tentang yang akan dihadapi siswa ke depan, mengingat hal tersebut, maka siswa setidaknya mempunyai pola pikir akan pentingnya masa depan hidup mereka ke depan. Sebagaimana dari hasil penelitian Asmaun Sahlan menunjukkan bahwa:

pelaksanaan pembentukan karakter mahasiswa dengan melalui PAI di Perguruan tinggi umum yaitu: (1) dengan mengadakan dialog interakatif tentang pemikiran agama Islam secara universal, (2) memasukkan mata kuliah di semua jurusan, (3) menyediakan lomba-lomba ilmiah yang bertemakan tentang penitingnya akan karakter mahawasiswa yang sebagai pemimpin masa depan, (4) menjadikan mereka (mahasiswa) sebagai teman dalam melakukan pendidikan agama Islam di kelas masing-masing, dan (5) mahasiswa diwajibkan memiliki buku pedoman pendidikan agama Islam PTU yang sudah disediakan.( Asmaun Sahlan,2013:77). 
Uraian tersebut di atas jika dielaborasikan dengan teori-teori yang ada, maka jelas bahwa karakter mulia berarti individu memiliki pengetahuan tentang potensi dirinya yang ditandai dengan nilai-nilai seperti reflektif, percaya diri, rasional, logis, kritis, analitis, kreatif dan inovatis, mandiri, hidup sehat, bertanggungjawab, cinta ilmu, sabar, berhati-hati, rela berkorban, pemberani, dapat dipercaya, jujur, menepati janji, adil, rendah hati, malu berbuat salah, pemaaf, berhati lembut, setia, bekerja keras, tekun, ulet atau gigih, teliti, berinisiatif, berfikir positif, disiplin, antisipatif, inisiatif, visioner, bersahaja, bersemangat, dinamis, hemat atau efisien, menghargai waktu, pengabdian atau dedikatif, pengendalian diri, produktif, ramah, cinta keindahan (estetis), sportif, tabah, terbuka, tertib. Individu juga memiliki kesadaran untuk berbuat yang terbaik atau unggul dan individu juga mampu bertindak sesuai potensi dan kesadarannya tersebut. ${ }^{1}$ Karakteristik adalah realisasi perkembangan positif sebagai individu (intelektual, emosional, sosial, etika dan perilaku). Individu yang berkarakter baik atau unggul secara tegas adalah seseorang yang berusaha melakukan hal-hal terbaik bagi Tuhan, dirinya sesama, lingkungan, bangsa dan Negara serta dunia pada umumnya dengan mengoptimalkan potensi (pengetahuan) dirinya disertai kesadaran, emosi dan motivasinya.

Pelaksanaan pembentukan karakter siswa dengan melalui pendidikan agama Islam di sekolah umum jelas memberikan sebuah arti sendiri bagi pengembangan karakter seorang manusia yang baik pula ke depan. Selain itu pula pelaksanaannya dilakukan secara inovatif, sehingga para guru khususnya guru agama dan mahasiswa tidak gampang bosan dengan pelaksanaan tersebut.

Dalam penerapan nilai-nilai pembentukan karakter siswa di sekolah tidak lepas dengan peran aktif dari lembaga/sekolah, guru, dan masyarakat. Peran lembaga/sekolah dan guru dalam pembentukan karakter siswa melalui pendidikan agama Islam (PAI) di sekolah umum sangat diperlukan mengingat pembentukan karakter siswa dengan pendidikan agama Islam (PAI) merupakan sebuah esensi dalam berbagai peningkatan yang diinginkan oleh sebuah lembaga khususnya lembaga pendidikan. Jika hal tersebut terlaksana dengan baik, maka akan menjadi

\footnotetext{
${ }^{1}$ Abdul Majid dan Dian Andayani, Pendidikan Karakter..., op. cit., hal. 161
} 
sebuah idealisme tersendiri bagi perkembangan kemajuan dalam sebuah lembaga pendidikan.

\section{Kesimpulan}

Berbagai uraian tentang pendidikan agama Islam di sekolah umum dalam pembelajaran PAI sebagai pembentukan karakter siswa dapat disimpulkan bahwa nilai-nilai pendidikan agama Islam dalam kehidupan siswa mampu memberikan pendidikan yang mengarah pada akhlak atau etika seorang anak/siswa dalam kehidupan sehari-harinya. Selain itu pula pendidikan agama Islam tidak hanya mengajarkan tentang shalat, puasa, zakat dan haji, namun pendidikan agama Islam di sekolah memberikan wawasan kepada peserta secara universal. Sehingga peserta didik memahami tentang PAI di sekolah umum bukan sekedar kebutuhan mata pelajaran belaka akan tetapi mata pelajaran tersebut memberikan sumbangsih wawasan yang luas.

Pembentukan karakter siswa di sekolah umum yaitu dengan menggunakan tia pendekatan di antaraya adalah (1) pendekatan kognitif, (2) pendekatan afektif, dan (3) pendekatan perilaku. Hal tersebut didasarkan pada tiga unsur moralitas, yang biasa menjadi tumpuan kajian psikologi, yaitu perilaku, kognisi, dan afeksi. Sedangkan nilai-nilai pembentukan karakter siswa di sekolah umum dapat diimplementasikan adalah dengan menggunakan iqra', fikir dan dzikir. Sehingga para siswa mampu merealisasikan dalam kehidupan sehari-hari.

\section{DAFTAR PUSTAKA}

Ambar. Teguh Sulistiyani \& Rosidah,2003. Manajemen Sumber Daya Manusia: Konsep, Teori dan Pengembangan dalam Konteks Organisasi Publik, Yogyakarta: Graha Ilmu.

Azyumardi Azra,2002. Paradigma Baru Pendidikan Nasional: Rekonstruksi dan Demokratisasi, Jakarta: Buku Kompas, .

J.L. Elias.1989. How to Teach About Values: An Analytic Approach, Florida: Obert E. Krieger Pu-blishing Co., Inc,.

J.R. Rest,1992. "Komponen-komponen Utama Moralitas". Dalam Kurtines, W.M. \& Gerwitz, J.L. (Ed.), 1985. Moralitas, Perilaku Moral, dan Perkembangan Moral, (Terj.) Soelaeman, M.A. \& Dahlan, M.D, Jakarta: Universitas Indonesia.

Marimba, 2011. Pengantar Filsafat Pendidikan, Bandung: Rosdakarya. 
Masnur Muslich, 2013. Pendidikan Karakter: Menjawab Tantangan Krisis Multidimensional, cetakan Kedua, Jakarta: PT Bumi Aksara.

Pusat Bahasa Deparetemen Pendidikan Nasional, 2007.Kamus Besar Bahasa Indonesia, edisi Ketiga, Jakarta: Balai Pustaka.

R.H., Miller J.P. Hersh \& Fielding, G.D.1980.Model of Moral Education: An Appraisal, New York: Longman, Inc.

Rohmat Mulyana, 2004. Mengartikulasikan Pendidikan Nilai, Bandung: Alfabeta.

Superka,2012. Pendidikan Karakter, Jakarta: PT. Raja Grasindo Persada.

Sugeng Listyo 2008. Manajemen Pengembangan Mutu Sekolah/Madrasah, Malang: UIN-Malang Press,.

Sri Palupi, 2011.Upaya Membangun Karakter Mahasiwa Bidang Boda, Hasil Penelitian, Yogyakarta: UNY.

Tadkiroatun Musfiroh, dalam Sofan Amri, dkk,2011. Implementasi Pendidikan Karakter dalam Pendidikan: Strategi Analisis dan Pengembangan Karakter Siswa dalam Proses Pembelajaran, Jakarta: PT Prestasi Pustakaraya.

Zuhairini, dkk.2004. Metodologi Pembelajaran PAI, Malang: UNM Press, 2004.

Zakiah Daradjad, 1995.Metodik Khusus Pengajaran Agama Islam, Jakarta: Bumi Aksara.

Abdul Majid dan Dian Andayani, 2012.Pendidikan Karakter Perspektif Islam, Bandung: PT Remaja Rosdakarya.

Asmaun Sahlan, 2013. Pembentukan Karakter Mahasiswa melalui PAI di Perguruan Tinggi Umum: Studi Kasus di Politeknik Negeri Malang, Hasil Penelitian di Lembaga Penelitian Fakultas Tarbiyah UIN Maulana Malik Ibrahim Malang, . 